\title{
PENGEMBANGAN BUKU PEDOMAN REKRUTMEN TENAGA PENDIDIK POS PAUD TERPADU
}

\author{
Piki Herayani \\ Murtadlo \\ Warih Handayaningrum \\ Pascasarjana Manajemen Pendidikan Universitas Negeri Surabaya \\ pikiherayani79@gmail.com
}

\begin{abstract}
Abstrak: Kualitas tenaga pendidik PAUD sebagai Sumber Daya Manusia (SDM) dalam pendidikan menjadi salah satu faktor kualitas pengembangan system pengelolaan Pos PAUD Terpadu. Oleh karena itu, diperlukan rekrutmen atau Manajemen SDM (MSDM) guna mendukung terselenggaranya PAUD secara efektif dan efisien. Tujuan penelitian ini adalah untuk mendeskripsikan proses pengembangan, kualitas atau kelayakan dan keefektifan produk buku pedoman rekrutmen tenaga pendidik Pos PAUD Terpadu sebagai salah satu garda depan pendidikan dalam meningkatkan professional pendidik dan tenaga pendidik PAUD. Penelitian ini menggunakan pendekatan penelitian pengembangan atau (research and development), menggunakan model pengembangan Thiagarajan, dkk yang dikenal dengan istilah $4 D$ models, yaitu 1) pendefinisian; 2) perancangan; 3) pengembangan; dan 4) penyebaran. Teknik pengumpulan data menggunakan metode observasi, dokumentasi dan kuisioner sedangkan teknik analisis datanya menggunakan analisis deskritif kualitatif dan kuantitatif. Teknik pengukuran data menggunakan skala linkert. Uji coba keefektifan menggunakan desain before-after untuk pengujian perbedaan sebelum dan sesudah perlakuan uji signikansi dengan menggunakan uji-T test. Hasil penelitian menunjukkan bahwa 1) proses pengembangan buku pedoman rekrutmen tenaga pendidik PAUD, melalui 3 tahap define, design, develop; 2) kualitas atau kelayakan diperoleh dari hasil validasi skor MSDM sebesar 161 dengan presentase 98\%, hasil validasi skor PAUD sebesar 53 dengan presentase 96\%, hasil validasi skor bahasa sebesar 63 dengan presentase 97\%; 3) hasil keefektifan uji coba produk buku pedoman rekrutmen tenaga pendidik di PAUD menunjukkan bahwa penggunaan buku pedoman mempengaruhi efektifitas nilai signifikansinya sebesar 0,00 yang artinya nilai tersebut $<0,05$ sehingga dapat disimpulkan bahwa penggunaan buku pedoman dinyatakan efektif untuk digunakan.
\end{abstract}

Kata kunci: rekrutmen, manajemen SDM, pendidikan anak usia dini

Abstract: Quality early childhood educators as Human Resources (HR) in education is one factor of the quality management system of early childhood development. Therefore, it is necessary that recruitment or human resource management (HRM) in order to support the implementation of early childhood education effectively and efficiently. The purpose of this education research is to describe the recruitment of teachers in early childhood education as one of the vanguard of professional improvement of teachers and early childhood educators. This research approach is using research and development. The development models used is Four-D models, adopted from Thiagarajan, which has been modified into three-D models, define, design and develop. Data was collected by observation, documentation, and questionnaire while data analysis technique were analyzed and developed by qualitative descriptive and quantitative. Then data measurement technique used was Linkert scale. While in examining the effectiveness of the guidance book before-after design was used to find out the difference of before and after test then using t-test to know degree of significant. The result of research shows that: (1) the development process of guidance book of educators' recrutrment of childhood passed through three processes as Four-D models, being modified into Three-D models, (2) The result of material/content validity got 161 , with $98 \%$. It means that the guidance book is very good and ready-implemented while The result of language validity got 63 , with $97 \%$. It means that the guidance book is very good and ready-tested linguistically. (3) The result of the law-test shows that there is influence to the effectiveness of teacher's recrutment. While the significant score is 0,00 , means that score $<0,05$.

Keywords: recruitment, Human Resource Management, early childhood education 
Manajemen diperlukan agar pengelolaan sistem pendidikan di sekolah, melalui perngembangan visi, misi, dan mempunyai tujuan yang jelas. Banyak sekolah yang memiliki tenaga pendidik (guru) yang berkualitas, sarana dan prasarana yang memadai, peserta didik yang berkualitas tetapi gagal dalam mewujudkan dirinya sebagai sekolah yang berkualitas. Hal ini disebabkan karena tidak adanya visi, misi dan tujuan yang jelas dalam penerapan di sekolah, sehingga sulit mewujudkan koordinasi tim kerja. Maka mengingat sekolah salah satu lembaga pendidikan yang dipercaya masyarakat dan negara untuk menyiapkan sumber daya manusia (SDM) yang dibutuhkan untuk pembangunan bangsa, sekolah dituntut harus mampu menghasilkan out put yang berkualitas yaitu memiliki SDM yang pandai terampil dan berbudi pekerti luhur (Syukur, 2004: p.128).

Sistem pengelolaan SDM meliputi perencanaan, seleksi/perekrutan, penempatan, pengembangan, dan pemberhentian untuk menjamin mutu penyelenggaraan program akademik, serta remunerasi, penghargaan, dan sanksi, termasuk informasi tentang ketersediaan pedoman tertulis dan konsistensi pelaksanaannya. Untuk mewujudkan niat baik yang tertuang di dalam Undang-Undang Nomor 20 Tahun 2003 tersebut perlu adanya komitmen dari berbagai pihak, terutama pemerintah dalam mengakomodasikan keinginan para tenaga pendidik dalam tuntutan pengembangan kualitas.

Perekrutan menjadi suatu kegiatan yang penting dalam suatu manajemen sumber daya manusia, karena perekrutan merupakan awal dari suatu kegiatan untuk mendapatkan tenaga yang berkualitas bagi lembaga/ instansi/perusahaan. Menurut Mangkunegara (2009, $\quad$ p. 33) mendefinisikan perekrutan adalah suatu proses atau tindakan yang dilakukan oleh perusahaan untuk mendapatkan tambahan tenaga SDM melalui tahapan yang mencakup identifikasi dan evaluasi, menentukan kebutuhan SDM diperlukan lembaga/instansi/perusahaan, proses seleksi, penempatan dan orientasi SDM. Untuk itulah rekrutmen tenaga kerja dibutuhkan untuk menyaring pada pelamar yang ingin melamar. Dalam organisasi, rekrutmen ini menjadi salah satu proses yang penting dalam menentukan baik tidaknya pelamar yang akan melamar pada suatu organisasi tersebut.

Upaya pengembangan tenaga pendidik tidak terlepas dari peran pemerintah sebagai penyelenggara pendidikan. Pemerintah dan pihak-pihak yang terkait dengan pendidikan, tidak pernah berhenti berupaya meningkatkan profesionalisme dan kesejahteraan tenaga pendidik. Pemerintah telah melakukan langkah-langkah strategis dalam kerangka peningkatan kualifikasi, kompetensi, kesejahteraan, serta perlindungan hukum dan perlindungan profesi bagi mereka. Langkahlangkah strategis ini perlu diambil, karena apresiasi tinggi suatu bangsa terhadap seorang tenaga pendidik sebagai penyandang profesi yang bermartabat merupakan pencerminan sekal igus sebagai salah satu ukuran martabat suatu bangsa. Pada usaha untuk mencapai tujuan pendidikan nasional, diperlukan peran dari para tenaga pendidik dan tenaga kependidikan yang dimaksud adalah tenaga pendidik, kepala sekolah, pengelola, administrasi, tenaga teknisi serta instansi/lembaga pendidikan yang lain. Terkait dengan lingkup pendidikan di tingkat dasar (Danim, 2010: p. 55)

Rekrutmen tenaga pendidik sangat diperlukan untuk mengatasi permasalahan sumber daya manusia yang harus mampu bersaing. Apapun alasannya, jika terjadi kondisi lowong pada suatu pekerjaan, wajibnya diisi pekerjaan tersebut. Kebutuhan SDM untuk tenaga pendidik yang harus memiliki kualitas dalam pendidikan. Salah satu caranya adalah dengan rekrutmen yang harus benar-benar sesuai dengan standar rekrutmen pada umumnya.

Pelaksanaan rekrutmen yang baik diharapkan sekolah dan instansi pendidikan untuk mendapatkan tenaga pendidik dengan kualitas yang ditetapkan sekolah. Beberapa permasalahan yang sering terjadi dalam rekrutmen tenaga pendidik yaitu a) masalah perencanaan rekrutmen yang kurang matang sehingga sering kali terjadi kegagalan dalam pencapaian tujuan sekolah, b) kurangnya tenaga ahli dalam bidangnya, c) tenaga pendidik yang kurang memiliki gairah kerja dan motivasi.

Menurut Suparlan (2006 p. 72-73) bahwa guru sebagai profesi tenaga pendidik dan kependidikan merupakan salah satu unsur 
terpenting dalam meningkatkan mutu pendidikan. Tenaga kependidikan adalah anggota dari masyarakat yang akan mengabdikan diringa dan diangkat sebagai penunjang penyelenggaraan pendidikan yang meliputi pengelola satuan pendidikan, penilik, pamong belajar, pengawas, peneliti, pengembang, pustakawan, laboran dan teknisi sumber belajar. Pendidik adalah tenaga kependidikan yang berkualitas sebagai guru, dosen konselor, pamong belajar, widyaiswara, tutor, instruktur, fasilitator, dan sebutan lain yang sesuai dengan kekhususannya, serta partisipasi dalam penyelenggaraan pendidikan.

PAUD merupakan pendidikan non-formal untuk para peserta didik dengan usia 2-4 tahun. Tahun 2005 UNESCO menyatakan bahwa Indonesia merupakan salah satu negara yang angka partisipasi pendidikan usia dini termasuk terendah di ASEAN, baru sebesar 20\%. Persentase dari beberapa negara ASEAN yang lain adalah Negara Philipina 27\%, Vietnam 43\%, Thailand $86 \%$ dan Malaysia 89\%. Setelah mendapatkan persentase dari negara-negara lain, maka Program PAUD menjadi salah satu dari 10 prioritas program Depdiknas sehingga PAUD menjadi salah satu program pokok dalam pembangunan pendidikan di Indonesia (tertuang dalam RPJM Tahun 2004-2009 dan Renstra Depdiknas Tahun 2004-2009). Pada penghujung tahun 2009, diterbitkan Permendiknas No. 58 Tahun 2009 tentang Standar PAUD (formal dan non-formal). (Harini, 2003 p. 87). Oleh karena itu, tidak heran kalau pada akhirnya pendidikan usia dini memang suatu kebutuhan yang paling dasar. Menurut Unicef Indonesia, untuk mengejar nilai, peringkat dan peningakatan mutu pendidikan di Indonesia, program PAUD dari tahun 2012 hingga akhir tahun 2016 terdapat kenaikan peringkat secara presentase menjadi $63 \%$ tingkat pencapaiannya dan berhasil melampaui rerata pendidikan di Asia.

Pengembangan Buku pedoman rekrutmen tenaga pendidik Pos PAUD Terpadu, diharapkan dapat membantu pengelola maupun pemerintah dalam memahami, mendalami dan meningkatkan kualitas rekrutmen secara administratif tenaga pendidik Pos PAUD Terpadu yang tepat dan sesuai dengan standar sebagai tenaga pendidik. Pengguna buku pedoman rekrutmen adalah Kepala atau Pengelola PAUD dan tenaga pendidik sebagai pedoman awal dalam meningkatkan kualifikasi tenaga pendidik PAUD. Untuk itu peneliti melakukan penelitian dengan judul "PENGEMBANGAN BUKU PEDOMAN REKRUTMEN TENAGA PENDIDIK POS PAUD TERPADU".

\section{METODE PENELITIAN}

Pendekatan yang dipakai dalam penelitian Manajemen PAUD dalam Pengembangan Buku Pedoman Rekrutmen Guru PAUD adalah penelitian pengembangan atau research and development ( $R$ and $D)$. Penelitian pengembangan adalah penelitian yang bertujuan untuk mengembangkan pengetahuan, teori pendidikan yang sudah ada, atau menghasilkan suatu produk dibidang pendidikan. Penelitian yang menekankan pada kajian tentang proses perekrutan yang dikembangkan menjadi buku pedoman. Buku pedoman dalam penelitian ini adalah buku yang digunakan untuk meningkatkan kualitas penyeleksian tenaga pendidik PAUD di sekolah non formal PAUD.

Metode penelitian dan pengembangan atau Research and Development (R\&D) merupakan penelitian yang bertujuan untuk menghasilkan atau mengembangkan suatu produk (Paidi, 2010, p. 57). Produk R \& D dalam pendidikan dan pembelajaran bisa berupa kurikulum, model, sistem managemen, sistem pembelajaran, bahan/ media pembelajaran dan lain-lain (Paidi, 2010, p. 57)

Metode penelitian dan pengembangan yang digunakan untuk menghasilkan produk tertentu, dan menguji keefektifan produk tersebut. Untuk dapat menghasilkan produk tertentu digunakan penelitian yang bersifat analisis kebutuhan dan untuk menguji keefektifan produk tersebut supaya dapat berfungsi di masyarakat luas, maka diperlukan penelitian untuk menguji keefektifan produk tersebut. Jadi penelitian dan pengembangan bersifat longitudinal atau bertahap dan bersifat multy years (Sugiyono, 2009, p. 297)

Produk yang dikembangkan kemudian diuji kelayakannya dengan validitas dan uji coba produk untuk mengetahui sejauh mana peningkatan rekrutmen yang dapat menghasilkan kualitas tenaga pendidik yang sesuai dengan Standar Nasional Pendidikan.

Jenis penelitian ini adalah pengembangan bersiklus (penelitian tindakan). Penelitian tindakan ini difokuskan pada pengembangan 
buku panduan rekrutmen tenaga pendidik Pos PAUD Terpadu.

Model pengembangan ini adalah mengacu pada Four- $D$ atau model yang disarankan oleh Thiagarajan (Sugiyono, 2015 p. 37-39). Model ini terdiri dari 4 tahap pengembangan, yaitu Define, Design, Develop dan Deseminate (pendefinisian, pendataan, perancangan, pengembangan dan penyebaran). Pada model Four- $D$ ini dimaksudkan agar model tersebut dapat diimplementasikan dalam pendidikan sesuai karakteristik penelitian dengan mempertimbangkan tujuan penelitian.

Pilihan model Thiagarajan, Four- $D$, atas perimbangan model tersebut sesuai dengan pengembangan buku pedoman. Penelitian ini melalui proses identifikasi rekrtumen dengan konsep pokok yang akan dilaksanakan, disusun dalam bentuk hirarki, dan merinci konsep-konsep individu ke dalam hal yang kritis dan yang tidka relevan. Analisis membantu mengindentifikasi kemungkinan cara dan pelaksanaan rekrutmen dalam proses pengembangan.

Analisis konsep diperlukan guna mengidentifikasi pengetahuan-pengetahuan deklaratif atau procedural pada buku pedoman rekrutmen yang akan dikembangkan. Analisis konsep merupakan satu langkah penting untuk memenuhi prinsip kecukupan dalam membangun konsep atas materi-materi yang digunakan sebagai sarana pencapaian kompetensi dasar dan standar kompetensi.

Pada model pengembangan penelitian ini khususnya pada tahap disseminate atau penyebaran terbatas pada pendistribusian atau penyebaran di sekolah dan di simpan di perpustakaan, hal ini dilakukan peneiti karena keterbatasan waktu, biaya, serta belum merencanakan untuk taraf pendistribusian dalam skala besar. Pelaksanaan langkah model tersebut hanya dibatasi sampai pada uji coba produk. Langkah-langkah penelitian dan pengembangan ditunjukkan pada gambar di bawah ini.

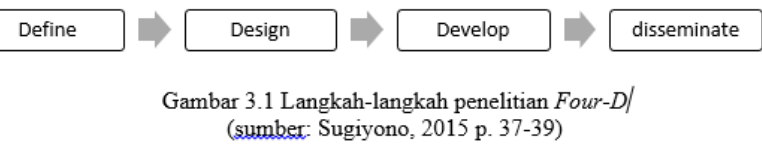

Langkah-langkah

pengembangan penelitian sebagai media pembelajaran dan pedoman rekrutmen mengacu pada model Four- $D$ yang meliputi tahap-tahap, yaitu: (1) Define, (2)

Subjek penelitian adalah tenaga pendidik PAUD di Sekolah PAUD Terpadu Kecamatan Karangpilang Surabaya. Jumlah penelitian ini adalah 2 rombongan rekrutmen dari pengelola sekolah PAUD. Subjek guru digunakan untuk melihat analisis kelemahan dan hambatan penerapan buku pedoman rekrutmen sehingga masukan dan saran dari guru atau pengelola menjadi instrument maupun pengembangan buku pedoman.

Adapun lokasi uji coba buku pedoman tersebut dilaksanakan terhadap tenaga pendidikan di PAUD Terpadu Kecamatan Karangpilang Surabaya. Pemilihn lokasi uji coba ini didasarkan atas pertimbangan: 1) Uji coba dilaksanakan di PAUD Terpadu Kecamatan Karangpilang Surabaya yang memiliki beberapa tenaga pendidik yang tidak sesuai dengan kualitas pendidik, 2) Peneliti sebagai warga di daerah PAUD Terpadu Kecamatan Karangpilang Surabaya, yang mengetahui kurangnya kualitas tenaga pendidik yang sesuai SNP.

Dalam pengumpulan data, penulis harus menyesuaikan situasi dan kondisi dilapangan. Adapun teknik pengumpulan data yang dapat digunakan oleh peneliti terdapat beberapa cara yaitu: 1) Penelitian perpustakaan (Library Research), 2) Penelitian lapangan (Field Work Research). Kuisioner diberikan kepada validator dan responden yang melakukan penilaian terhadap produk pengembangan. Dalam penelitian ini ada 5 (lima) validator ahli yaitu ahli manejemen SDM, ahli pendidikan non-formal (PAUD), dan ahli bahasa. Dokumentasi adalah teknik pengumpulan data dengan menggunakan dokumen sebagai sumber data. Dokumentasi adalah pengumpulan data dari tempat penelitian, yaitu meliputi buku-buku yang relevan, peraturan-peraturan, laporan kegiatan, fotofoto, film dokumenter, dan data-data dari penelitian terdahulu yang relevan dengan masalah atau tujuan penelitian. Metode dokumentasi biasanya sebagai penunjang metode lain untuk memperoleh data tambahan yang terkait dengan Instrumen validasi produk 
Instrumen pengumpulan data yang digunakan dalam penelitian dan pengembangan untuk menghasilkan produk pedoman rekrutmen tenaga pendidik Pos PAUD Terpadu menggunakan pedoman observasi dan kuisioner. Pedoman ini untuk mengetahui kebutuhan pengguna. Menguji produk rekrutmen tenaga pendidik Pos PAUD Terpadu (uji ahli, ujicoba kelompok kecil dan ujicoba luas) menggunakan angket penilaian. Untuk pengembangan produk rekrutmen tenaga pendidik Pos PAUD Terpadu digunakan angket untuk mengetahui kebutuhan rekrutmen tenaga pendidik Pos PAUD Terpadu.

Uji validasi produk rekrutmen tenaga pendidik Pos PAUD Terpadu ini yaitu dari beberapa ahli dan pengguna yang akan bertindak sebagai validator untuk memberikan penilaian dan masukan berupa kritikan dan saran terhadap buku pedoman rekrutmen tenaga pendidik Pos PAUD Terpadu. Adapun para validator tersebut ditetapkan sebagai berikut: a) Ahli manajemen sumber daya manusia (SDM), b) Ahli pendidikan non-formal (PAUD), c) Ahli bahasa.

Sedangkan yang menentukan kelayakan dari hasil uji coba skala kecil adalah nilai dari pre-test dan post-test seluruh kepala atau pengelola PAUD yang sedang menggunakan buku pedoman.

Data penelitian terkumpul seluruhnya, penulis menganalisis data tersebut sesuai, maka tahapan akhir dari hasil laporan ini adalah analisis data. Teknik analisis data yang digunakan penulis adalah teknik analisis deskriptif kualitatif yaitu penulis dalam menganalisis berkeinginan untuk memberikan gambaran atau pemaparan atas data dan sumber data penelitian sebagaimana hal penelitian yang dilakukan.

\section{Analisis kelayakan produk}

Analisis kelayakan produk buku pedoman rekrutmen tenaga pendidik Pos PAUD Terpadu terdiri atas validasi materi dan validasi bahasa. Validasi buku pedoman rekrutmen tenaga pendidik Pos PAUD Terpadu dilakukan untuk menetukan kevalidan buku pedoman tersebut berdasarkan kriteria-kriteria validasi yang ditetapkan. Instrument yang digunakan berupa lembar validasi. Data kuantitatif dari hasil validasi dianalisis menggunakan statistic deskriptif yaitu menggunakan penskoran dari tiap item instrument yang hasilnya di rata-rata selanjutnya dilakukan teknik penghitungan presentase.

Rumus yang digunakan diadaptasi dari Hobri, 2010 p.42, yaitu:

$P=\sum_{i=1}^{n} \underset{n k}{x_{i}} \times 100 \%$

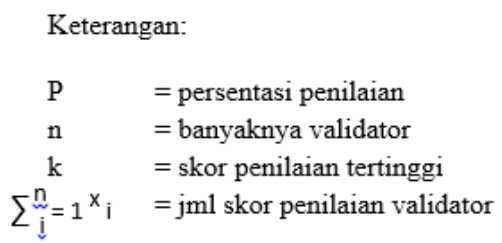

\section{HASIL DAN PEMBAHASAN}

Hasil Proses Pengembangan Produk Buku Pedoman rekrutmen tenaga pendidik Pos PAUD Terpadu

Penelitian Awal

Penelitian awal dilakukan untuk menganalisis (a) kebutuhan lapangan calon pengguna terhadap produk yang dikembangkan, (b) menganalisis spesifikasi produk yang dibutuhkan oleh lapangan. Informan penelitian awal adalah kepala atau pengelola PAUD, beserta tenaga pendidik PAUD, setelah mengikuti beebrapa pelatihan tentang tenaga pendidik PAUD.

\section{Proses Pengembangan Produk}

Proses pengembangan buku pedoman rekrutmen tenaga pendidik Pos PAUD Terpadu ini menggunakan Four-D Models. Model pengembangan penelitian ini terdiri dari empat tahap: (a) define, (b) design, (c) develop,

(d) disseminate. Dalam pelaksanaan penelitian pengembangan buku pedoman rekrutmen tenaga pendidik Pos PAUD Terpadu ini hanya dilaksanakan sampai pada tahap ketiga, yaitu (a) tahap pendefinisian (define), (b) tahap perancangan (design), dan (c) tahap pengembangan (develop) atau diadaptasi peneliti menjadi 3-D, karena pada tahap penyebaran (disseminate) tidak dapat dilakukan. Hal ini dilakukan peneiti karena keterbatasan waktu, biaya, serta belum merencanakan untuk taraf pendistribusian dalam skala besar.

\section{Tahap Pendefinisian (define)}

Tahap ini menentukan dan mendefinisikan syarat-syarat pengembangan produk. Terdapat 5 (lima) langkah pokok dalam tahap ini, yaitu analisis kebutuhan, 
analisis pembelajar, analisis tugas, konsep dan perumusan tugas.

\section{Analisis awal (front-end analysis)}

Analisis awal, langkah ini digunakan untuk menentukan masalah mendasar yang dihadapi dalam rekrutmen tenaga pendidik di Kecamatan Karangpilang Surabaya. Penelitian awal meliputi identifikasi masalah dan pengumpulan informasi yang dibutuhkan dalam penelitian pengembangan, sehingga dari informasi yang didapatkan dapat dilakukan untuk menganalisis beberapa hal, yaitu (a) kebutuhan lapangan calon pengguna terhadap produk yang dikembangkan, (b) menganalisis spesifikasi produk yang dibutuhkan oleh lapangan. Berdasarkan analisis penelitian awal inilah sebagai dasar untuk pengembangan pedoman rekrutmen tenaga pendidik Pos PAUD Terpadu.

\section{Analisis pembelajar (learner analysis)}

Analisis pembelajar, langkah ini dilakukan untuk menelaah kualitas tenaga pendidik. Dilakukan identifikasi terhadap karakteristik tenaga pendidik yang sesuai dengan rancangan dan pengembangan rekrutmen. Hasil dari analisis rekrutmen tenaga pendidik Pos PAUD Terpadu akan dijadikan sebagai bahan pertimbangan untuk mengembangkan sejauh mana buku pedoman yang akan dibuat dan mampu diterima oleh kepala atau pengelola PAUD mampu meningkatkan standartisasi kualifikasi tenaga pendidik PAUD. Dari hasil analisis pedoman rekrutmen tenaga pendidik Pos PAUD Terpadu belum semua kepala atau pengelola PAUD memahami secara komprehensif tentang tugas dan perlunya rekrutmen sesuai dengan standar tenaga pendidik PAUD.

\section{Analisis tugas (task analysis)}

Analisis tugas dan konsep adalah kumpulan prosedur untuk menentukan isi dalam produk yang dikembangkan, analisis tugas dilakukan untuk merinci isi materi buku pedoman rekrutmen dengan implementasi buku pedoman. Kepala atau pengelola PAUD mampu memahami buku pedoman rekrutmen tenaga pendidik Pos PAUD Terpadu dengan membaca dan memahami buku pedoman. Analisis tugas disesuaikan dengan tujuan dan target rekrutmen tenaga pendidik Pos PAUD Terpadu.

\section{Analisis konsep (concept analysis)}

Analisis konsep yang dilakukan untuk menentukan atau merumuskan tujuan dan proses rekrutmen yang dicapai oleh kepala atau pengelola PAUD dan instansi/lembaga terkait. Analisis yang membantu mengidentifikasi kemungkinan contoh dan bukan contoh untuk menggambarkan selama dalam proses pengembangan. Analisis konsep sangat diperlukan guna mengidentifikasi pengetahuan secara dekalratif dan procedural pada produk yang dikembangkan

\section{Analisis tujuan (specifying instructional objectives)}

Perumusan tujuan pengembangan bermanfaat untuk menentukan perilaku objek penelitian. Kumpulan objek tersebut menjadi dasar untuk menyusun tes dan merancang suatu buku pedoman. Adapun tujuan produk dan uraian tugas yang telah tersusun, yaitu (1) menghasilkan media yang berupa buku pedoman tentang rekrutmen tenaga pendidik Pos PAUD Terpadu (2) menghasilkan produk yang bertujuan untuk mengetahui proses dan prosedur rekrutmen tenaga pendidik Pos PAUD Terpadu.

\section{Hasil Kelayakan Produk Buku Pedoman rekrutmen tenaga pendidik Pos PAUD Terpadu}

Tujuan tahap pengembangan ini adalah menghasilkan bentuk akhir buku pedoman rekrtumen tenaga pendidik PAUD setelah melalui revisi berdasarkan masukan para ahli/praktisi dan data hasil uji coba. Tahap pengembangan ini meliputi langkah-langkah sebagai berikut:

\section{Kevalidan Produk yang Dikembangkan}

Dari hasil desain pengembangan yang telah dibuat maka langkah selanjutnya adalah melakukan validasi terhadap buku "Pedoman rekrutmen tenaga pendidik Pos PAUD Terpadu".

\section{Validasi ahli manajemen SDM}

Produk yang diserahkan kepada ahli manajemen SDM adalah Buku Pedoman rekrutmen tenaga pendidik Pos PAUD Terpadu. Pada uji ahli putaran pertama, penilaian difokuskan pada komentar, saran, kritik terhadap buku 

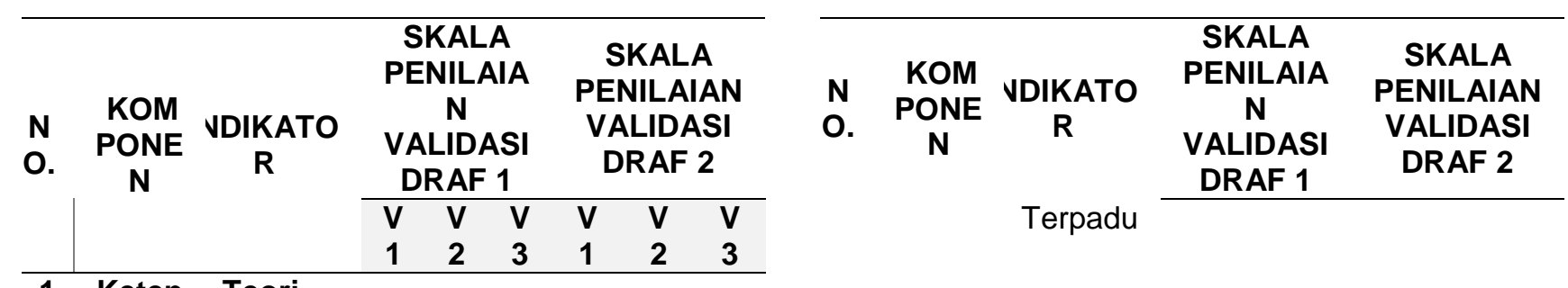

\begin{tabular}{lll}
\hline 1 & Ketep & Teori \\
atan & Penduk \\
Teori & ung
\end{tabular}

a.

Relevan

si teori

penduku

ng

dengan

rekrutm

en

tenaga

pendidik

Pos

PAUD

Terpadu

b.

Kekomp

rehensi-

fan teori

penduku

ng

rekrutm

en

tenaga

pendidik

Pos

PAUD

Terpadu

c.

Kesesua

ian

materi

dan

tujuan

rekrutm

en

tenaga

pendidik

Pos

PAUD

Terpadu

d.

Keakura

tan

konsep

dan teori

rekrutm

en

tenaga

pendidik

Pos

PAUD $\begin{array}{llllll}4 & 3 & 4 & 5 & 4 & 5\end{array}$

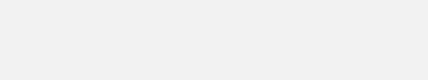

$\begin{array}{llllll}4 & 4 & 4 & 4 & 5 & 5\end{array}$

$\begin{array}{llllll}5 & 4 & 4 & 5 & 5 & 5\end{array}$

2

\section{Kedal Kegiata \\ aman $\mathbf{n}$ \\ Materi Rekrut \\ men}

a.

Kejelasa

n urutan

kegiatan

rekrutm

en

tenaga

pendidik

Pos

PAUD

Terpadu

b.

Cakupa

n

langkah-

langkah

kegiatan

rekrutm

en

tenaga

pendidik

Pos

PAUD

Terpadu

c.

Tingkat

keterlak

sanaan

langkah-

langkah

kegiatan

rekrutm

en

tenaga

pendidik

Pos

PAUD

Terpadu $\begin{array}{llllll}4 & 4 & 4 & 5 & 5 & 5\end{array}$

$\begin{array}{llllll}4 & 4 & 3 & 5 & 4 & 4\end{array}$

$\begin{array}{llllll}5 & 3 & 4 & 5 & 4 & 5\end{array}$ 


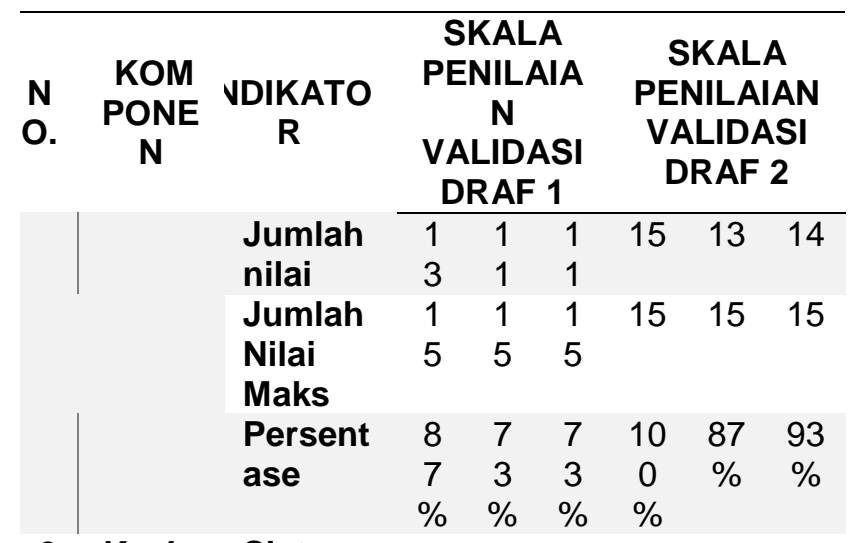

3 Keak Sistem uratan Rekrut Materi men
a.
Kejelasa
n yang
dikehen
daki
dalam
kegiatan
rekrutm
en
tenaga
pendidik
Pos
PAUD
Terpadu

b.

Kemung

kinan

terwujud

nya

situasi

dan

kondisi

dalam

kegiatan

rekrutm

en

tenaga

pendidik

Pos

PAUD

Terpadu

$\begin{array}{lllllll}\text { Jumlah } & 8 & 9 & 8 & 10 & 9 & 10\end{array}$

nilai

$\begin{array}{lllllll}\text { Jumlah } & 1 & 1 & 1 & 10 & 10 & 10\end{array}$

Nilai

Maks

$\begin{array}{lllllll}\text { Persent } & 8 & 9 & 8 & 10 & 90 & 10\end{array}$

$\begin{array}{lllllll}\text { ase } & 0 & 0 & 0 & 0 & \% & 0\end{array}$

4

Kemu Prinsip

takhir Rekrut

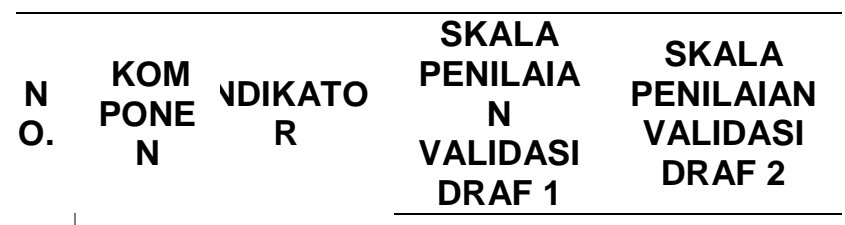

an men

Materi

Relevan

si

lembaga

pendidik

, Kepala

Sekolah/

Pengelol

a PAUD

dengan

karakteri

stik dan

indikator

i

rekrutm

en

tenaga

pendidik

Pos

PAUD

Terpadu

b.

Kejelasa

$\mathrm{n}$

perilaku

lembaga

pendidik

, Kepala

Sekolah/

Pengelol

a dalam

kegiatan

rekrutm

en

tenaga

pendidik

Pos

PAUD

Terpadu

$\begin{array}{llllll}4 & 4 & 4 & 5 & 5 & 5\end{array}$

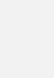

(a)

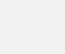


Tabel 4.4 Uraian Validator Ahli Bahasa

\begin{tabular}{|c|c|c|c|}
\hline NO. & INDIKATOR & $\begin{array}{c}\text { SKALA } \\
\text { PENILAIAN } \\
\text { VALIDASI } \\
\text { DRAF } 1\end{array}$ & $\begin{array}{c}\text { SKALA } \\
\text { PENILAIAN } \\
\text { VALIDASI } \\
\text { DRAF } 2 \\
\end{array}$ \\
\hline \multirow[t]{8}{*}{1} & Format Buku & & \\
\hline & a. Sistem penomoran jelas. & 4 & 5 \\
\hline & $\begin{array}{l}\text { b. Pengaturan ruang/tata } \\
\text { letak }\end{array}$ & 4 & 5 \\
\hline & $\begin{array}{l}\text { c. Jenis dan ukuran huruf } \\
\text { sesuai SOP }\end{array}$ & 4 & 4 \\
\hline & $\begin{array}{l}\text { d. Kesesuain antara buku } \\
\text { fisik dan kebutuhan }\end{array}$ & 4 & 5 \\
\hline & Jumlah nilai & 16 & 19 \\
\hline & Jumlah Nilai Maksimal & 20 & 20 \\
\hline & Persentase & $80 \%$ & $95 \%$ \\
\hline \multirow[t]{4}{*}{2} & Bahasa Buku & & \\
\hline & $\begin{array}{l}\text { a. Bahasa jelas, sesuai EYD } \\
\text { dan mudah dipahami }\end{array}$ & 3 & 4 \\
\hline & $\begin{array}{l}\text { b. Menampakkan informasi } \\
\text { yang jelas }\end{array}$ & 4 & 5 \\
\hline & c. Urutan penyajian yang & 4 & 5 \\
\hline
\end{tabular}

\section{Hasil Keefektifan Produk Buku Pedoman rekrutmen tenaga pendidik Pos PAUD Terpadu}

Data hasil uji coba skala kecil terhadap keefektifan produk buku pedoman rekrutmen tenaga pendidik Pos PAUD Terpadu yang dipaparkan pada bagian ini ada 13 kisi pertanyaan tentang manfaat dan kejelasan tentang proses rekrutmen; langkah-langkah prosedur rekrutmen; istilah, model, rancangan rekrutmen; keterbacaan dan pemahaman tentang rekrumen tenaga pendidik PAUD; dan standar operasional dalam rekrutmen tenaga pendidik.

Buku pedoman yang dikembangkan tentunya juga akan berperan penting terhadap respon kepala atau pengelola PAUD terhadap pelaksanaan program rekrutmen yang dilaksanakan. Respon didapat sebelum menjelaskan materi rekrutmen dan setelah membaca mengenai materi dan bahan yang terdapat dalam buku pedoman. Respon kepala atau pengelola PAUD diketahui dari angket yang diisi pada uji coba skala kecil. Kepala atau pengelola PAUD diarahkan dalam membaca pedoman rekrutmen tenaga pendidik Pos PAUD Terpadu sebagai acuan dalam proses dan prosedur rekrutmen yang akan dilaksanakan.
Pada pengujian pengembangan dari analisis data yang sudah ada diperlukan uji TTest dengan menggunakan Paired Sample $T$ test dan uji normalitas. Adapun hasil analisis respon kepala atau pengelola PAUD pada uji coba skala kecil adalah sebagai berikut Jika nilai probabilitas atau Sig. (2-tailed) $<0,05$, maka terdapat perbedaan yang signifikan antara hasil kuisioner pada data pre-test dan post-test yang artinya terdapat pengaruh penggunaan buku pedoman rekrutmen tenaga pendidik Pos PAUD Terpadu. Sebaliknya jika nilai probabilitas atau Sig. (2-tailed) > 0,05, maka TIDAK terdapat perbedaan yang signifikan antara hasil kuisioner pada data pre-test dan post-test yang artinya terdapat pengaruh penggunaan buku pedoman rekrutmen tenaga pendidik Pos PAUD Terpadu.

Berdasarkan output data yang ada diketahui bahwa nilai probabilitas atau Sig. (2tailed) sebesar 0,000<0,05, karena nilai Sig. (2-tailed) sebesar 0,000 lebih kecil 0,05, maka dapat disimpulkan bahwa penggunaan buku pedoman rekrutmen tenaga pendidik Pos PAUD Terpadu dapat meningkatkan kualifikasi dan proses rekrutmen tenaga pendidik Pos PAUD Terpadu.

\section{KESIMPULAN}

Berdasarkan hasil penelitian tentang buku pedoman rekrutmen tenaga pendidik Pos PAUD Terpadu, maka dapat disimpulkan sebagai berikut: (1) Proses pengembangan produk buku pedoman rekrutmen tenaga pendidik Pos PAUD Terpadu menggunakan model pengembangan atau (research and development), dengan model pengembangan Thiagarajan, dkk yang dikenal dengan istilah 4- $D$ models, yaitu (a) pendefinisian; (b) perancangan, (c) pengembangan; dan (d) penyebaran. (2) Kelayakan buku pedoman rekrutmen tenaga pendidik Pos PAUD Terpadu berdasarkan uji validasi ahli yaitu ahli bidang manajemen SDM, ahli bidang PAUD, ahli bidang bahasa adalah menyatakan bahwa produk pengembangan layak valid dan layak digunakan, (3) kefektifan produk buku pedoman rekrutmen tenaga pendidik Pos PAUD Terpadu, berdasarkan hasil analisi data pada uji skala kecil ditinjau dari segi penguasaan materi dapat disimpulkan bahwa penggunaan pedoman rekrutmen tenaga 
pendidik Pos PAUD Terpadu dapat digunakan dan efektif.

\section{SARAN}

Saran yang dipaparkan dipilah menjadi tiga bagian yaitu: saran pemanfaatan, saran diseminasi, saran pengembangan produk lebih lanjut.

\section{Saran Pemanfaatan.}

Bagi pemerintah dalam hal ini Dinas Pendidikan dan Kebudayaan sebagai tenaga pendidik PAUD. Dengan melakukan analisis kebutuhan terlebih dahulu supaya melahirkan program yang dapat digunakan oleh komponen pendidik. Sebagai salah satu pedoman rekrutmen tenaga pendidik yang sesuai dengan standar pendidikan nasional.

Bagi kepala atau pengelola PAUD dapat menggunakan pedoman ini menyesuaikan dengan sumber daya serta kebutuhan dalam rekrtumen tenaga pendidik.

Bagi tenaga pendidik PAUD dapat menjadi inspirasi dan motivasi dalam meningkatkan kualitas dalam segi kompetensi tenaga pendidik.

\section{Saran Penyebaran (disseminate)}

Buku pedoman ini baru dikembangkan pada kepala atau pengelola PAUD di Kecamatan Karangpilang Surabaya, dapat dilanjutkan dengan proses rekrutmen yang lebih luas misalnya pada tingkatan provinsi. Buku pedoman rekrutmen tenaga pendidik dapat dilanjutkan dengan proses rekrtumen yang lebih luas misalnya pada tingkatan provinsi.

\section{Saran Pengembangan}

Bagi tenaga pendidik PAUD perlu memperhatikan kualifikasi sebagai tenaga pendidik PAUD yang berkompetensi

Bagi peneliti berikutnya perlu melakukan penelitian dan pengembangan dengan uji skala besar, dengan harapan pengujian secara kualitas lebih sempurna

Bagi kepala atau pengelola PAUD maupun UPT perlu memperhatikan prosedur dan kualifikasi rekrutmen tenaga pendidik PAUD. Bagi Dinas Pendidikan dan Kebudayaan perlu memberikan arahan dan aturan sesuai standar operasional tentang rekrutmen dan kualifikasi tenaga pendidik PAUD.

\section{DAFTAR RUJUKAN}

Agip, Zainal dkk. 2009. Penelitian tindakan kelas untuk guru $S D$, SLB, dan TK. Bandung: Yrama Widya Bandung.

Agung, I. 2010. Meningkatkan kreativitas pembelajaran bagi guru. Jakarta: Bestari Buana Murni.

Arikunto, Suharsimi., dkk. 2004. Pengembangan kapasitas kepengawasan pendidikan di wilayah kota Yogyakarta. Jurnal Penelitian Bappeda Kota Yogyakarta, Vol.1, No.1, Desember, ISSN 1978-0052

2007. Dasar-dasar evaluasi Pendidikan (edisi revisi). Jakarta: Bina Aksara.

Asmawati, Luluk Dkk. 2013. Pengelolaan Kegiatan Pengembangan Anak Usia Dini. Jakarta: Universitas terbuka.

Barthos, Basir. 2004. Manajemen sumber daya manusia. Jakarta : Bumi Aksara.

Bogdan, Robert. C. dan Biklen, Sari Knopp. 2002. Qualitative research for education: an introduction to theory and methods. Boston: Allyn and Bacon. Inc.

Danim, Sudarwan. 2004. Motivasi kepemimpinan dan efektivitas kelompok. Jakarta: PT. Rineka Cipta.

Denzim, Norman. K dan Lincoln, Yvonna. S. 2004. Entering the field of qualitative research. dalam Denzim, Norman, K \& Lincoln, Yvonna. S. Handbook of Qualitative Research. California: Sage Publication. Inc.

Departemen Pendidik Nasional. 2006. Standar Kompetensi dan kompetensi dasar. Jakarta: Direktorat Jenderal Manajemen Pendidikan Dasar dan Direktorat Pembinaan Non-Formal.

2008. Kamus besar bahasa Indonesia. Jakarta: Balai Pustaka.

Gomes, Foustino Cardoso. 2003. Manajemen sumber daya manusia. Yogyakarta: ANDI 
Gunartha, I Wayan. 2014. Pengembangan model evaluasi program layanan pendidikan anak usia dini (PAUD). Jurnal Penelitian dan Evaluasi Pendidi

Kompri. 2015. Manajemen pendidikan (Komponen-komponen elementer kemajuan sekolah). Yogyakarta: ArRuzz Media.

Mangkunegara, A.A. Anwar Prabu. 2009. Manajemen sumber daya manusia perusahaan. Bandung: PT. Rosda

Mathis. Robert L. \& Jackson, John H. 2001. Manajemen sumber daya manusia (Human Resource Management). Penerjemah Jimmy Sadeli \& Bayu Prawira Hie. Jakarta: PT. Salemba Patria.

Miles, M. B. \& Huberman, A. M. 1984. Qualitative data analysis. Beverly Hill: Sage Publication Inc.

Mulyasa. 2012. Manajemen PAUD. Bandung: PT. Remaja Rosdakarya.

Nawawi, H. Hadari. 2000. Manajemen sumber daya manusia. Yogyakarta: Gadjah Mada University Press.

Noe, Raymond A., 2010. Human resource management, gaining competitive advantage $3^{\text {rd }}$ Edition. McGraw-Hill.

Pranata, M. 2009. Metodologi penelitian terapan. Malang: Universitas Negeri Malang

Prastowo, Andi. 2011. Panduan kreatif membuat bahan ajar inovatif, menciptakan metode pembelajaran menarik dan menyenangkan. Jakarta: Diva Press.

Pidarta, Made. 2009. Supervisi Pendidikan Kontekstual. Jakarta: Rineka Cipta. Surabaya: Unesa Press.

2011. Manajemen Pendidikan Indonesia. Jakarta: Rineka Cipta.

Riduwan. 2014. Manajemen Pendidikan. Bandung: Alfabeta.
Rivai, Veithzal. 2006. Manajemen Sumber Daya Manusia Untuk Perusahaan. Jakarta : Murai Kencana.

Roopnarine, Jaipaul L. \& James E. Johnson. 2011. Pendidikan anak usia dini: dalam berbagai pendekatan. Edisi 5. Jakarta: Prenadamedia Grup.

Sagala, Syaiful. 2006. Konsep dan makna pembelajaran. Bandung: Alfabeta.

2010. Kemampuan profesional guru dan tenaga kependidikan. Bandung: Alfabeta.

Sonhadji, A. 2006. Contoh-contoh catatan lapangan serta paparan data dan temuan penelitian. Bahan Suplement Seminar-Lokakarya Metode Penelitian Kualitatif. Malang: Universitas Negeri Malang.

Sihotang, A. 2007. Manajemen sumber daya manusia. Jakarta: Pradnya Paramita.

Sitepu, B.P. 2008. Buku teks pelajaran berbasis aneka sumber. Jurnal Pendidikan Penabur - No.10/Tahun ke7/Juni 2008.

Sugiyono, 2011. Metode penelitian kuantitatif, kualitatif dan $R \& D$. Bandung: Alfabeta

2015. Metode penelitian dan pengembangan (Research and Development). Bandung: Alfabeta.

Sujiono, Yuliani Nurani. 2009. Konsep dasar pendidikan anak usia dini. Jakarta: PT. Indek.

Sukiman. 2008. "Teori pembelajaran dalam pandangan konstruktivisme dan pendidikan islam", Kependidikan Islam. Yogyakarta: Pustaka Pelajar

Suparlan. 2006. Guru sebagai profesi, Cet. 1. Yogyakarta: Hikayat Publising.

Susilo, Setiadi. 2016. Pedoman Penyelenggaraan PAUD. Jakarta: Bee Media Pustaka.

2016. Pedoman Akreditasi PAUD. Jakarta: Bee Media Pustaka. 
Sutarman, Maman \& Asih. 2016. Manajemen Pendidikan Usia Dini (Filosofi, Konsep, Prinsip, dan Aplikasi). Bandung: CV. Pustaka Setia

Suyadi, M.Pd. \& Maulida Ulfah. 2013. Konsep dasar PAUD. Bandung: PT. Remaja Rosdakarya Offset.

Syukur, Fatah. 2004. Teknologi pendidikan. Semarang: CV. Rosail

Winardi. 1983. Asas-asas manajemen. Bandung : Offset Alumni.

Yamin, H. Martinis. 2012. Desain Baru Pembelajaran Konstruktivistik. Yogyakarta: Pustaka Pelajar.

Yin, Robert K. 2007. Studi kasus: desain dan metode. Ed. 1. Cet. 1. Penerjemah M. Djauzi Mudzakir. Jakarta: PT RajaGrafindo Persada.

Yullyanti, Ellyta. 2009. Analisis proses rekrutmen dan seleksi pada kinerja pegawai. Jakarta: PT. Indeks 